\title{
Dynamics of antifolate transport via the reduced folate carrier and the membrane folate receptor in murine leukaemia cells in vitro and in vivo
}

\author{
Robert Mauritz · Godefridus J. Peters · Ietje Kathmann · Habte Teshale • \\ Paul Noordhuis · Elizabeth M. Comijn · Herbert M. Pinedo · Gerrit Jansen
}

Received: 9 November 2007 / Accepted: 12 January 2008 / Published online: 19 February 2008

(C) The Author(s) 2008

\begin{abstract}
Murine L1210 leukaemia cells expressing either the reduced folate carrier (RFC) or the membrane folate receptor (MFR) were studied in vitro and in vivo to assess the dynamics of membrane transport of two categories antifolates; folate-based inhibitors of dihydrofolate reductase (methotrexate, edatrexate, aminopterin, PT523, and PT644) and thymidylate synthase (TS) [CB3717, raltitrexed, plevitrexed (BGC9331), pemetrexed and GW1843]. The potency of in situ inhibition of TS was used as an endpoint to analyze the in vitro dynamics of RFC/ MFR-membrane transport of these antifolates. Both for L1210-RFC and L1210-MFR cells, the potency of in situ TS inhibition was closely correlated with increasing affinities of these transporters for the antifolates $(r=0.64$, $P<0.05$ and $r=-0.65, P<0.05$, respectively). Within the group of antifolates for which MFR had a low binding affinity, those that had the ability to become polyglutamylated, were more potent inhibitors of TS in situ activity than non-polyglutamatable antifolates. In vivo activity of methotrexate, edatrexate, raltitrexed and pemetrexed was assessed in L1210-RFC and L1210-MFR bearing mice that were fed either a standard or a folate-deficient chow. Dietary folate depletion significantly reduced the MTD for methotrexate (sevenfold), edatrexate (sevenfold), raltitrexed (50-fold) and pemetrexed (150-fold). Based on increased life spans, antitumor effects of methotrexate and
\end{abstract}

R. Mauritz · G. J. Peters $(\bowtie) \cdot$ I. Kathmann $\cdot$ H. Teshale ·

P. Noordhuis · E. M. Comijn · H. M. Pinedo

Department of Medical Oncology, VU University Medical Center,

P.O. Box 7057, 1007 MB Amsterdam, The Netherlands

e-mail: gj.peters@vumc.nl

G. Jansen

Department of Rheumatology,

VU University Medical Center, Amsterdam, The Netherlands edatrexate were markedly better in L1210-RFC bearing mice on the folate-deficient chow (ILS: 455 and 544\%, respectively) than on standard chow (ILS: 213 and 263\%, respectively). No therapeutic effects of methotrexate and edatrexate were observed for L1210-MFR bearing mice on either chow condition, which may be consistent with the low binding affinity for MFR. Irrespective of the folate diet status, pemetrexed and raltitrexed were inactive against both L1210-RFC and L1210-MFR bearing mice, which may be due to high circulating plasma thymidine levels. Collectively, this study underscores that modulation of dietary folate status can provide a basis within which the therapeutic effect of antifolates may be further improved.

Keywords Methotrexate - Antifolates .

Reduced folate carrier - Membrane folate receptor .

Polyglutamylation - Thymidylate synthase .

Leukaemia cells

\section{Abbreviations}

\begin{tabular}{|c|c|}
\hline AMT & Aminopterin \\
\hline CB3717 & $N^{10}$-propargyl-5,8-dideazafolic acid \\
\hline DHFR & Dihydrofolate reductase \\
\hline EDX & Edatrexate \\
\hline FPGS & Folylpolyglutamate synthetase \\
\hline GW1843 & $\begin{array}{l}\text { (S)-2[5-(((1,2-dihydro-3-methyl-1- } \\
\text { oxobenzo(f)quinazolin-9-yl)-methyl)- } \\
\text { amino)1-oxo-2-isoindolinyl]-glutaric acid }\end{array}$ \\
\hline HBSS & HEPES-buffered saline solution \\
\hline $\mathrm{IC}_{50}$ & $\begin{array}{l}\text { Drug concentration required for } 50 \% \text { growth } \\
\text { inhibition compared to controls }\end{array}$ \\
\hline ILS & Increase in life span \\
\hline LV & Leucovorin (5-formyltetrahydrofolate) \\
\hline MFF & Membrane folate receptor \\
\hline ITD & Maximum tolerated dose \\
\hline
\end{tabular}




\begin{tabular}{|c|c|}
\hline MTX & Methotrexate \\
\hline PMX & Pemetrexed \\
\hline РT523 & $\begin{array}{l}N^{\alpha} \text {-(4-amino-4-deoxypteroyl)- } N^{\delta} \text {-(hemiphta- } \\
\text { loyl-L-ornithine) }\end{array}$ \\
\hline РT644 & 5-Methyl-5-deaza-PT523 \\
\hline RFC & Reduced folate carrier \\
\hline RTX & Raltitrexed \\
\hline TS & Thymidylate synthase \\
\hline $\mathrm{TSI}_{50}$ & $\begin{array}{l}\text { Drug concentration required to inhibit } 50 \% \\
\text { of TS activity compared to untreated controls }\end{array}$ \\
\hline BGC9331 & $\begin{array}{l}\text { Plevitrexed/(2S)-2-(0-fluoro-p-[N-(2,7-dime- } \\
\text { thyl-4-oxo-3,4-dihydroquinazolin-6-ylme- } \\
\text { thyl)- } N \text {-(prop-2-ylnyl)amino] benzamido)-4- } \\
\text { (tetrazol-5-yl) butyric acid }\end{array}$ \\
\hline
\end{tabular}

\section{Introduction}

Several distinct routes for the uptake of folates and antifolates have been reported. Of these the reduced folate carrier (RFC) and membrane folate receptors (MFR) are thoroughly characterized [4, 14, 24, 25, 31, 52, 71]. The RFC is an integral membrane glycoprotein that generates folate uptake by a carrier-mediated process through a bi-directional anion exchange mechanism $[25,31]$. The RFC is characterized by a high affinity $\left(K_{m}: 1-10 \mu \mathrm{M}\right)$ for reduced folates and methotrexate (MTX), whereas it has poor affinity for oxidized folates such as folic acid $\left(K_{m}: 200-400 \mu \mathrm{M}\right)$.

Membrane folate receptors are membrane-associated folate binding proteins that constitute a second group of folate transporters and are characterized by high binding affinity for folic acid $\left(K_{d}: 0.1-1 \mathrm{nM}\right)$ and 5-methyltetrahydrofolate $\left(K_{d}: 3 \mathrm{nM}\right)$, but markedly lower affinities for other reduced folates and MTX [26, 29, 44, 64].

Three isoforms of MFR ( $\alpha, \beta$ and $\gamma)$ with distinct binding affinities for folates and antifolates, have been identified. MFR- $\alpha$ and MFR- $\beta$ are linked to the cell membrane by a glycosylphosphotidylinositol-anchor [65], whereas MFR- $\gamma$ is a secretory form and lacks this anchor [44]. Two mechanisms of internalization of folates by MFR have been proposed: classical endocytosis [47] and a process called potocytosis which involves the sequestration of MFRs in specific membrane vesicles (caveolae) in which, upon acidification, the (anti) folates dissociate from the receptors and are transported into the cytosol by a putative folate carrier [2]. Although the exact role and the relative importance of the RFC in mediating antifolate antitumor activity in vivo has been fairly well established [5, 29, 31, 50], the role of MFR is still unclear [12, 67]. However, it may be anticipated that optimal MFR-mediated transport could be revealed under conditions of low extracellular folates when there is less receptor occupancy and competition with circulating reduced folates $[15,61,68]$.
In addition to influx into cells, the cytotoxic action of MTX and other antifolates is dependent on binding to the intracellular targets dihydrofolate reductase (DHFR) [35] and thymidylate synthase (TS) [40], polyglutamylation [33, 34], and the rate of drug efflux via members of the multidrug resistance protein family [3, 18, 63]. TS is a key enzyme in the de novo synthesis of thymidylate necessary for DNA synthesis. It catalyzes the conversion of deoxyuridine monophosphate (dUMP) into deoxythymidine monophosphate (dTMP), for which 5, 10-methylenetetrahydrofolate is the methyl donor. Inhibition of TS results in depletion of dTMP, which can lead to thymineless death due to inhibition of DNA synthesis [1]. Polyglutamylation is the process of elongation of the (anti) folate molecule by the addition of multiple glutamate moieties to the $\gamma$-carboxyl group of the glutamate side chain. This process is catalyzed by folylpolyglutamate synthetase (FPGS) and results in increased retention of (anti) folates within the cell and increased affinity for some key enzymes [36].

Aminopterin (AMT) $[10,58]$ and edatrexate (EDX) [55] are DHFR inhibitors that are better transported via the RFC and better substrates for FPGS than MTX (Table 1). PT523 and PT644 are novel DHFR inhibitors that exhibit efficient RFC transport but their hemiphtaloyl-ornithine side chain withholds them from being polyglutamylated [46, 49]. MFR exhibits, relative to folic acid, a low binding affinity for the group of DHFR inhibitors MTX, EDX and PT523, whereas a relatively high binding affinity is noted for the group of antifolate TS inhibitors (Table 1).

In addition to DHFR, other crucial enzymes in folate metabolism, such as TS, have been exploited as targets for the development of novel antifolates [20, 39]. CB3717 was the first folate-based TS inhibitor, which was withdrawn from clinical development because of renal toxicity [19]. In recent years new antifolate-based TS-inhibitors have been approved for clinical use, including raltitrexed (RTX) [9, 53] and pemetrexed (PMX; ALIMTA ${ }^{\mathrm{TM}}$ ) [16]. Other TS inhibitors such as GW1843 (reformulated as a liposomal compound: GS7904L) and BGC9331 (plevitrexed, ZD9331) are currently being evaluated in clinical trials $[6,8,13,21]$. RTX [23] and GW1843 [13] are more efficiently transported via the RFC and better substrates for FPGS than MTX. BGC9331 is a non-polyglutamatable TS inhibitor that displays efficient transport both via the RFC and MFR [21]. PMX mainly inhibits TS but polyglutamate metabolites of this drug are also potent inhibitors of DHFR and glycinamide ribonucleotide formyltransferase, a key enzyme in the de novo purine synthesis [56]. Moreover, PMX is a good substrate for FPGS and RFC and has high binding affinity for MFR [56].

Previous studies from our laboratory $[66,68]$ and others $[60,64]$ have assessed the differential role of RFC and MFR in the growth inhibitory effects of antifolates in terms 
Table 1 Transport and polyglutamylation properties of antifolates

\begin{tabular}{|c|c|c|c|c|}
\hline & $\begin{array}{l}\text { Affinity } \\
\text { RFC }^{\mathrm{a}}\end{array}$ & $\begin{array}{l}\text { Affinity } \\
\text { MFR }^{b}\end{array}$ & $\begin{array}{l}\text { Affinity } \\
\text { FPGS }^{c}\end{array}$ & References \\
\hline \multicolumn{5}{|c|}{ DHFR inhibitors } \\
\hline MTX & 10.8 & 0.009 & ++ & {$[68]$} \\
\hline AMT & 2.2 & 0.012 & +++ & {$[68]$} \\
\hline EDX & 1.7 & 0.009 & +++ & {$[51,68]$} \\
\hline PT523 & 1.1 & 0.005 & - & {$[45,68]$} \\
\hline PT644 & 0.45 & 0.18 & - & {$[49,68]$} \\
\hline \multicolumn{5}{|c|}{ TS inhibitors } \\
\hline CB3717 & 57 & 1.4 & ++ & {$[68]$} \\
\hline BGC9331 & 0.85 & 0.72 & - & {$[21,68]$} \\
\hline RTX & 2.0 & 0.68 & ++++ & {$[23,68]$} \\
\hline GW1843 & 0.8 & 0.55 & ++++ & {$[13,68]$} \\
\hline PMX & 4.5 & 1.48 & ++++ & {$[56,68]$} \\
\hline
\end{tabular}

${ }^{\text {a }} \mathrm{RFC}$ affinity is expressed as the concentration of drug $(\mu \mathrm{M})$ required to inhibit $5 \mu \mathrm{M}\left[{ }^{3} \mathrm{H}\right] \mathrm{MTX}$ influx in human CEM-7A leukaemia cells by $50 \%[68]$

b MFR-affinity is depicted as relative affinity compared to folic acid (set to 1). Relative affinity is defined as the inverse molar ratio of drug required to displace $50 \%$ of $\left[{ }^{3} \mathrm{H}\right]$-folic acid from MFR in L1210-MFR cells [68]

${ }^{c}$ FPGS substrate activity $\left(K_{m}\right)$ is defined as follows: $++++K_{m}<5 \mu \mathrm{M}$, $+++K_{m} 5-25 \mu \mathrm{M},++K_{m} 25-100 \mu \mathrm{M},+K_{m}>100 \mu \mathrm{M},-$ non-substrate

of affinity relationships. In this study, we focused on the dynamics of membrane transport of a series of antifolates (MTX, EDX, AMT, PT523, PT644, CB3717, RTX, BGC9331, GW1843 and PMX) via the RFC and/or MFR using the in situ inhibition of TS as an endpoint. These studies should provide insight whether MFR binding affinity is correlated with the efficacy of cell entry and capacity to inhibit TS. Model systems used were L1210 murine leukaemia cells expressing RFC as sole folate transport system [17], and L1210-MFR cells that lack functional RFC activity but harbour high MFR expression [28]. In addition, we extended these studies to an in vivo setting in which the antitumor effect of two antifolates with a low MFR binding (EDX and MTX) was compared with two antifolates with high MFR binding capacity (RTX and PMX). Since folate levels in mouse plasma may be amply sufficient to saturate MFR [54, 62], we also performed experiments in mice kept on a folate-depleted diet aiming to achieve a greater percentage of unoccupied receptors that could bind antifolates.

\section{Materials and methods}

Chemicals

RPMI 1640 cell culture medium, with and without folic acid, and (dialyzed) foetal calf serum (FCS) were obtained from Cambrex Bio Science (Verviers, Belgium). Leucovorin, folic acid and AMT were purchased from Sigma Chemical Co. (St Louis, MO). MTX was a gift from Pharmachemie (Haarlem, The Netherlands). Edatrexate (EDX) was a gift from Dr. J.H. Schornagel, Netherlands Cancer Institute, Amsterdam, The Netherlands. Raltitrexed (Tomudex, ZD1694) was from AstraZeneca Pharmaceuticals (Macclesfield, UK). CB3717 and BGC9331 were gifts from Prof. A.L. Jackman, Inst. of Cancer Research (Sutton, Surrey, UK). GW1843 was provided by Dr G.K. Smith, GlaxoWellcome Research Laboratories, currently Glaxo Smith Kline (Research Triangle Park, NC). PT523 was a gift from Dr. W.T. McCulloch (then at Sparta Pharmaceuticals, Research Triangle Park, NC). PT644 (5-methyl-5-deazaPT523) was provided by Dr. A. Rosowsky (Dana-Farber Cancer Institute, Boston, MA). Pemetrexed (PMX, ALIMTA $^{\mathrm{TM}}$ ) was a gift of Lilly Research Laboratories (Indianapolis, IN). The radiochemicals $\left[3^{\prime}, 5^{\prime}, 7-{ }^{3} \mathrm{H}\right]-\mathrm{MTX}(23 \mathrm{Ci} /$ mmol), $\left[3^{\prime}, 5^{\prime}, 7,9-{ }^{3} \mathrm{H}\right]$-AMT $(13 \mathrm{Ci} / \mathrm{mmol}),\left[3^{\prime}, 5^{\prime}, 7,9-{ }^{3} \mathrm{H}\right]-$ Folic acid $(69 \mathrm{Ci} / \mathrm{mmol})$ and $\left[5-{ }^{3} \mathrm{H}\right]-2^{\prime}$-deoxycytidine (28 Ci/mmol) were obtained from Moravek Biochemicals (Brea, CA). All other chemicals were of the highest purity available.

\section{Cell lines}

L1210-RFC cells, a murine leukaemia cell line that expresses wild type RFC, was cultured in RPMI-1640 medium (containing $2.3 \mu \mathrm{M}$ folic acid), supplemented with $10 \%$ FCS, $2 \mathrm{mM}$ glutamine, penicillin (100 units $/ \mathrm{ml}$ ), streptomycin $(100 \mu \mathrm{g} / \mathrm{ml})$, and $50 \mu \mathrm{M} \beta$-mercaptoethanol. L1210-MFR cells overexpress MFR but lack functional RFC activity $[28,68]$ and were grown in folate-free RPMI1640 medium, supplemented with $10 \%$ dialyzed FCS and $2.5 \mathrm{nM} \mathrm{L}-\mathrm{LV}$ as the sole folate source. The cell lines were maintained at $37^{\circ} \mathrm{C}$ in a humidified atmosphere with $5 \%$ $\mathrm{CO}_{2}$. The cells had comparable levels of DHFR, TS and FPGS [68].

In situ TS inhibition assay

Inhibitory effects of antifolates on in situ TS activity were determined as described previously $[32,48]$. In short, cells were washed and suspended in folate-free RPMI-1640 medium and samples of $2 \times 10^{5}$ cells in a volume of $150 \mu \mathrm{l}$ were exposed to various concentrations of antifolate drugs for $3,6,9,12$ or $24 \mathrm{~h}$ at $37^{\circ} \mathrm{C}$. One hour before the end of the incubation, $10 \mu 1\left[5-{ }^{3} \mathrm{H}\right]-2^{\prime}$-deoxycytidine was added to the cell suspensions to a final concentration of $1 \mu \mathrm{M}$ (specific activity, $0.7 \mu \mathrm{Ci} / \mathrm{nmol})$. $\left[{ }^{3} \mathrm{H}\right]-2^{\prime}$-deoxycytidine is converted intracellularly to $\left[{ }^{3} \mathrm{H}\right]$-dUMP, which is the substrate of TS. TS catalyses the conversion of $\left[{ }^{3} \mathrm{H}\right]$-dUMP to dTMP and during this reaction $\left[{ }^{3} \mathrm{H}\right] \mathrm{H}_{2} \mathrm{O}$ is released in the medium, which is a marker of uninhibited TS activity [69]. The 
reaction was stopped by the addition of $150 \mu$ ice-cold $35 \%$ trichloroacetic acid solution. After the addition of $750 \mu 110 \%$ charcoal solution, the suspensions were mixed and centrifuged at $800 \times g$ for $30 \min \left(4^{\circ} \mathrm{C}\right)$. A $450 \mu$ supernatant sample was counted for radioactivity. Inhibition of TS activity was expressed as a TSI $_{50}$ value: the drug concentration required for $50 \%$ inhibition of TS activity of control cells incubated without drugs.

Determination of accumulation and polyglutamate formation of MTX and AMT

L1210-RFC and L1210-MFR cells $\left(10 \times 10^{6}\right.$ in $10 \mathrm{ml}$ medium) were incubated in $25 \mathrm{~cm}^{2}$ tissue flasks in the presence of different concentrations of $\left[{ }^{3} \mathrm{H}\right]-\mathrm{MTX}$ (specific activity $0.45 \mu \mathrm{Ci} / \mathrm{nmol}$ ) or $\left[{ }^{3} \mathrm{H}\right]$-AMT (specific activity $0.65 \mu \mathrm{Ci} / \mathrm{nmol}$ ). After 1,4 and $24 \mathrm{~h}$, cells were washed twice with ice-cold HEPES-buffered saline solution (HBSS) pH 7.4 by centrifugation and the pellet was resuspended in $1 \mathrm{ml}$ HBSS. A sample of $90 \mu \mathrm{l}$ was counted for radioactivity, $10 \mu \mathrm{l}$ was used to determine the number of cells, the remaining suspension was centrifuged and the pellet was kept at $-20^{\circ} \mathrm{C}$ until extraction. The extraction of $\left[{ }^{3} \mathrm{H}\right]-\mathrm{MTX}$ and $\left[{ }^{3} \mathrm{H}\right]$-AMT polyglutamates and HPLC analysis were performed as described previously [7].

Mice

Female DBA/2 mice (7-10 weeks) were obtained from Harlan (Zeist, The Netherlands) and maintained under standard conditions [62]. Mice were fed either a standard chow (containing $3.65 \mathrm{mg}$ folic acid per $100 \mathrm{~kg}$ ) or a folate deficient $(0 \mathrm{mg}$ folic acid per $100 \mathrm{~kg}$ ) chow (Hope Farms, Woerden, The Netherlands), which was given ad libitum. The animals for low folate diet experiments were fed with the folate deficient chow for at least 2 weeks prior to the onset of experiments. Under these conditions folate levels in tissues and plasma are reduced within 2 weeks to that observed in humans [62].

To assess the maximum tolerated doses (MTD) of MTX, EDX, RTX and PMX for mice on a standard diet and for mice on a low folate diet, various doses of each drug were tested (3 mice per dose). MTX and EDX were administered on day 0 and day 7; RTX and PMX were injected once daily on day $0-4$. All of the drugs were administered intraperitoneally. All animal experiments were approved by the Animal Ethical Committee of the VU University.

\section{Determination of anti-leukaemic activity}

Mice were intraperitoneally inoculated with wild type L1210 cells $\left(1 \times 10^{6}\right.$ per mouse $)$ or L1210-MFR cells $\left(2 \times 10^{6}\right)$. Since the doubling rate of L1210 cells is approximately 1.5 -fold higher than the variants, the number of injected cells was adjusted accordingly. Treatment was started $24 \mathrm{~h}$ after inoculation using the established MTD of the drugs. Mice ( 5 per group) received bolus injections with MTX or EDX on day 0 and day 7, whereas RTX or PMX were injected daily on day $0-4$.

Weight and clinical condition were determined daily. Survival was assessed daily for up to 93 days and was counted from the start of injection of the cells. Mice identified as moribund (visual inspection and/or $>20 \%$ weight loss) were sacrificed by cervical dislocation and survival time was considered the number of days alive plus one. The antileukaemic activity of the antifolates was assessed by calculating the percentage of the increase in life span (ILS), i.e., the ratio of the median survival of treated mice over the median survival of the untreated control group $\times 100 \%$.

Ex vivo folic acid binding studies

Ascites was collected from sacrificed mice for determination of $\left[{ }^{3} \mathrm{H}\right]$-folic acid binding capacity. Ascites L1210MFR cells were isolated by centrifugation with FicollIsopaque. One part of the cells was washed with HBSS buffer ( $\mathrm{pH}$ 7.4) and used for measurement of folic acid binding capacity. The other part of the cells was washed twice with folate free RPMI-1640 medium and subsequently resuspended in folate free RPMI-1640 medium supplemented with $10 \%$ dialyzed FCS for a period of $24 \mathrm{~h}$. Cells were counted with a haemocytometer and viability was determined by Trypan-blue dye exclusion.

Folic acid binding capacity of isolated L1210-MFR cells was assessed as described previously [26]. In short, one portion of cells $\left(3-5 \times 10^{6}\right.$ cells $\left./ \mathrm{ml}\right)$ was incubated in HBSS pH 7.4 with 100 pmol $\left[{ }^{3} \mathrm{H}\right]$-folic acid (specific activity $0.5 \mathrm{Ci} / \mathrm{mmol}$ ) for $10 \mathrm{~min}$ at $4^{\circ} \mathrm{C}$. Then cells were centrifuged and the cell pellet was analyzed for radioactivity. The total folic acid binding capacity was determined after a 20 min acidic treatment with HBSS buffer (pH 3.5) to remove surface bound folates [29]. After centrifugation, cells were resuspended in HBSS pH 7.4 and incubated with $\left[{ }^{3} \mathrm{H}\right]$-folic acid as described above. Another portion of L1210-MFR cells were resuspended in folate-free RPMI-1640 medium and cultured in vitro for $24 \mathrm{~h}$ after which folic acid binding capacity was assessed again.

\section{Statistics}

For the relation between TS inhibitory potency of the antifolates and growth inhibitory effect or folate transporter affinities, the Spearman ranking correlation coefficient was calculated. $P$ values $<0.05$ were considered to be statistically significant. 


\section{Results}

In situ TS inhibition studies

The inhibitory effects of $3 \mathrm{~h}$ exposure of the antifolate compounds MTX, AMT, EDX, PT523, PT644, CB3717, BGC9331, RTX, GW1843 and PMX on in situ TS activity of L1210-RFC cells and L1210-MFR cells are listed in Table 2. All drugs, with the exception of CB3717, displayed rapid and potent inhibition of TS activity in the L1210-RFC cells. A significant correlation was observed between the $\mathrm{TSI}_{50}$ values for this panel of antifolates and their RFC substrate affinities $(r=0.64 ; P<0.05$; Fig. 1a). Furthermore, $\mathrm{TSI}_{50}$ values for L1210-RFC cells obtained with the 3-h in situ TS inhibition assay revealed a strong correlation ( $r=0.69 ; P<0.05$; Fig. 1 b) with the previously published $\mathrm{IC}_{50}$ values for cell growth inhibition after $72 \mathrm{~h}$ drug exposure [68]. For L1210-MFR cells, an inverse relation was found between the increasing MFR antifolates binding affinities and the $3-\mathrm{h} \mathrm{TSI}_{50}$ values $(r=-0.65$; $P<0.05$; Fig. 1c). Finally, a strong correlation $(r=0.87$, $P<0.01$; Fig. 1d) was observed between the 3 -h $\mathrm{TSI}_{50}$ values and the IC50 values for growth inhibition of L1210MFR cells after 72-h drug exposure.

In L1210-MFR cells, the TSI T0 $_{5}$ value for $3 \mathrm{~h}$ exposure to MTX, PT523 and PT644 were more than 300-fold higher compared to the $\mathrm{TSI}_{50}$ values in L1210-RFC cells (Table 2), which may be consistent with the low MFR

Table 2 Inhibitory effects of antifolates on in situ TS activity of L1210-RFC and L1210-MFR cells

\begin{tabular}{lcc}
\hline & TSI $_{50}(\mathrm{nM})$ & \\
\cline { 2 - 3 } & $\mathrm{L}^{2} 10-\mathrm{RFC}$ & $\mathrm{L} 1210-\mathrm{MFR}$ \\
\hline DHFR inhibitors & & \\
MTX & $46.3 \pm 7.6$ & $17,870 \pm 1,690$ \\
AMT & $25.3 \pm 6.1$ & $172 \pm 15$ \\
EDX & $20.3 \pm 3.7$ & $2,013 \pm 113$ \\
PT523 & $8.2 \pm 0.5$ & $35,056 \pm 5,877$ \\
PT644 & $7.3 \pm 0.2$ & $33,550 \pm 4,150$ \\
TS inhibitors & & \\
CB3717 & $2,805 \pm 680$ & $7,200 \pm 2,180$ \\
BGC9331 & $10.0 \pm 0.9$ & $7.8 \pm 4.6$ \\
RTX & $17.0 \pm 2.7$ & $5.9 \pm 1.7$ \\
RTX (200 nM FA) & & $2,070 \pm 415$ \\
GW1843 & $57.4 \pm 4.9$ & $91.4 \pm 30.7$ \\
PMX & $45.2 \pm 4.5$ & $20.7 \pm 2.9$ \\
\hline
\end{tabular}

Cells were incubated for $3 \mathrm{~h}$ with a concentration range of drugs (covering $2 \log$ concentrations). The in situ TS activity was determined by incubating cells with $\left[5-{ }^{3} \mathrm{H}\right]$-deoxycytidine and measuring release of $\left[{ }^{3} \mathrm{H}\right]-\mathrm{H}_{2} \mathrm{O}$. TSI $\mathrm{T}_{50}$ values were determined in at least three different experiments

L1210-RFC parental cells (RFC+), L1210-MFR (RFC-/MFR+++) binding affinity for these compounds (Table 1). Interestingly, however, MFR also exhibits a poor binding affinity for AMT and EDX (Table 1), but these two DHFR inhibitors demonstrated a much more potent TS inhibitory effect (Table 2). Within the group of TS inhibitors, PMX, GW1843, BGC9331 and RTX all displayed a good TS inhibitory effect after $3 \mathrm{~h}$ exposure (Table 2). Supplementation of medium with $200 \mathrm{nM}$ folic acid had a marked (351fold) protective effect against TS inhibition by RTX in L1210-MFR cells (Table 2), consistent with MFR being the dominant transport route for RTX in these cells. Surprisingly, CB3717, for which MFR has a relatively high binding affinity and RFC a low affinity (Table 1), displayed a low potency of TS inhibition after $3 \mathrm{~h}$ drug exposure in L1210-MFR cells, being just 2.6-fold lower than for L1210-RFC cells (Table 2). The TS-inhibitory activity of RTX, BGC9331 and PMX in L1210-MFR was comparable with that of L1210-RFC cells (Table 2).

Time dependency

Since data presented in Table 2 indicated that TS in situ inhibition for some antifolates in L1210-MFR cells (in contrast to L1210-RFC cells) was not fully displayed after $3 \mathrm{~h}$ of exposure, experiments were extended to $24 \mathrm{~h}$ drug exposure. The TS inhibitory effects of the different antifolates in L1210-MFR cells in relation to exposure-time are depicted in Fig. 2a (for DHFR inhibitors) and Fig. 2b (for TS inhibitors). Extension of the exposure time from 3 to $24 \mathrm{~h}$ resulted in a 3-log increase of the TS inhibitory effect of MTX against L1210-MFR cells; in particular, a marked increase in MTX-activity occurred between 6 and $9 \mathrm{~h}$ (Fig. 2a). The non-polyglutamatable DHFR inhibitors PT523 and PT644 gained increasing TS inhibitory activity over 3-12 $\mathrm{h}$ exposure after which the effect levelled off (Fig. 2a). CB3717 demonstrated higher TS inhibitory activity than MTX after short-term exposures ( $\leq 6 \mathrm{~h}$ ), however, this property was lost beyond $9 \mathrm{~h}$ of drug incubation (Fig. 2b). For comparison, short exposures of L1210-MFR cells to the TS inhibitors RTX and BGC9331 were already sufficient to achieve their maximal TS inhibitory activity.

Accumulation and polyglutamylation of MTX and AMT

In order to establish whether differences (Table 2) in $\mathrm{TSI}_{50}$ for two compounds with similar MFR binding affinity, MTX and AMT (Table 2), could be explained by factors downstream of transport, we analyzed accumulation and polyglutamate formation of $\left[{ }^{3} \mathrm{H}\right]-\mathrm{MTX}$ and $\left[{ }^{3} \mathrm{H}\right]-\mathrm{AMT}$ in L1210-RFC and L1210-MFR cells (Table 3). Following 1, 4 and $24 \mathrm{~h}$ exposures to $1 \mu \mathrm{M}\left[{ }^{3} \mathrm{H}\right]-\mathrm{MTX}$ and $\left[{ }^{3} \mathrm{H}\right]-\mathrm{AMT}$, accumulation of both antifolates in L1210-MFR cells was 1,5-3-fold lower than in L1210-RFC cells. For both cell 
Fig. 1 a Correlation of RFC affinity for antifolates and $\mathrm{TSI}_{50} \mathrm{nM}$ after $3 \mathrm{~h}$ drug exposure to L1210-RFC cells, b Correlation between $\mathrm{IC}_{50} \mathrm{nM}$ values of growth inhibition of L1210RFC cells after $72 \mathrm{~h}$ drug exposure and $\mathrm{TSI}_{50} \mathrm{nM}$ after $3 \mathrm{~h}$ drug exposure, $\mathbf{c}$ Correlation of MFR affinity for antifolates and $\mathrm{TSI}_{50} \mathrm{nM}$ after $3 \mathrm{~h}$ exposure to L1210-MFR cells, d Correlation between $\mathrm{IC}_{50} \mathrm{nM}$ values of growth inhibition of L1210MFR cells after $72 \mathrm{~h}$ drug exposure and $\mathrm{TSI}_{50} \mathrm{nM}$ after $3 \mathrm{~h}$ drug exposure
Fig. 2 Time-dependent inhibition of TS in situ activity in L1210-MFR cells by folate based DHFR inhibitors (a) and folate-based TS inhibitors (b). For comparison the effect of MTX is shown in both graphs
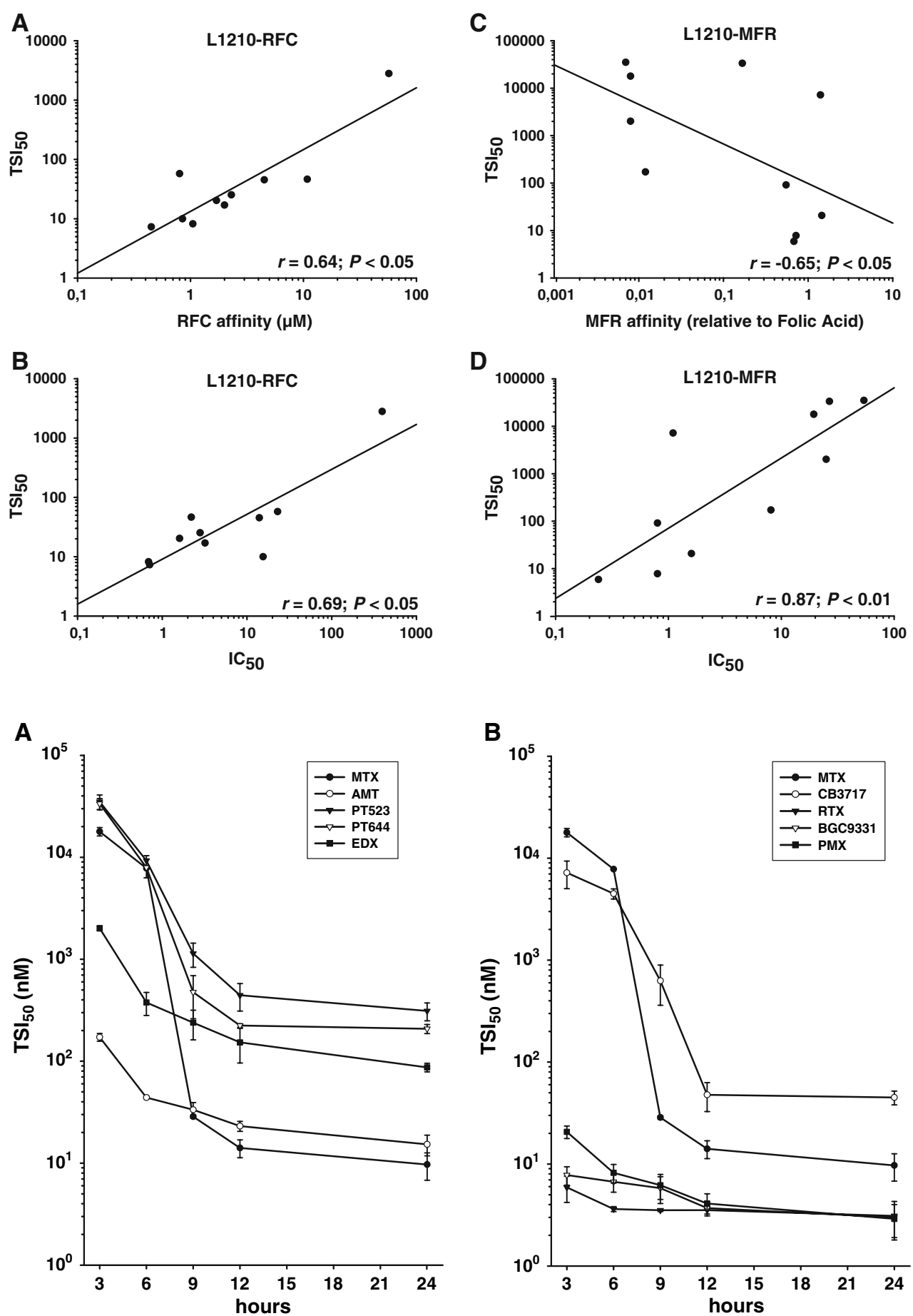

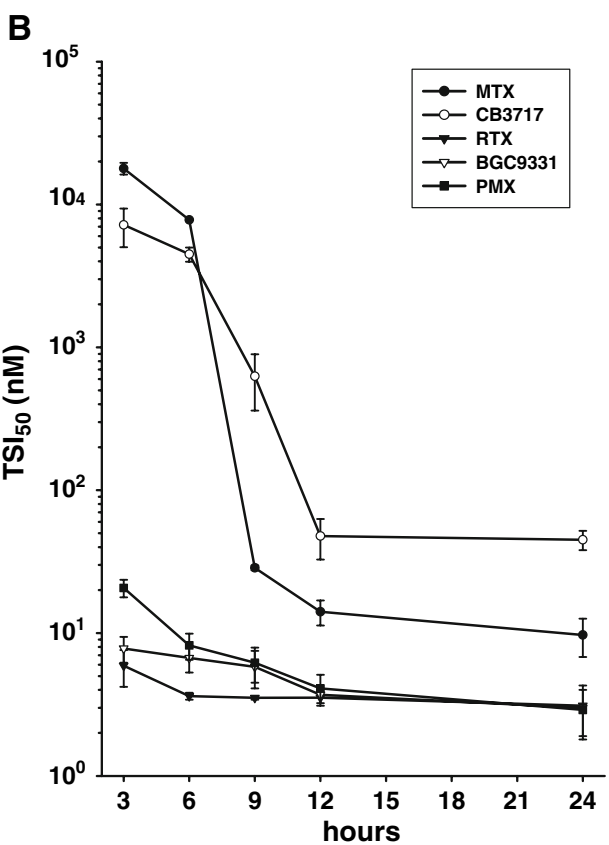

lines, however, formation of long chain polyglutamate forms of $\left[{ }^{3} \mathrm{H}\right]$-AMT was much more efficient than for $\left[{ }^{3} \mathrm{H}\right]$ MTX, which could be consistent with lower $\mathrm{TSI}_{50}$ values for AMT as compared to MTX, and with the higher affinities of AMT to FPGS compared to MTX.

In vivo dose-finding studies

The MTD for the four antifolates was determined both in mice on a standard folate diet and mice on a low folate diet.
The latter was done for two reasons. First, plasma folate levels of mice are approximately fourfold higher than in human plasma and may counteract activity of antifolates [62]. When mice were adapted to a folate-restricted diet, plasma levels were more in line with that of human plasma. Secondly, high plasma folate levels in mice may lead to full occupancy of MFR binding sites which requires a greater degree of competition for antifolates to displace natural folates. It is hypothesized that under a folate-restricted diet, MFR occupancy by natural folates will be lower to allow 
Table 3 Accumulation and polyglutamylation of MTX and AMT in L1210-RFC and L1210MFR cells
Cells were incubated for the indicated periods with either $1 \mu \mathrm{M}\left[{ }^{3} \mathrm{H}\right]-\mathrm{MTX}$ or $1 \mu \mathrm{M}\left[{ }^{3} \mathrm{H}\right]-$ AMT. Results depicted are the mean of duplicate experiments

\begin{tabular}{lclrccccc}
\hline Substrate & $\begin{array}{l}\text { Inc. } \\
\text { time (h) }\end{array}$ & $\begin{array}{l}\text { Accumulation } \\
\left(\mathrm{pmol} / 10^{7} \text { cells }\right)\end{array}$ & $\mathrm{Glu}_{1}(\%)$ & $\mathrm{Glu}_{2}(\%)$ & $\mathrm{Glu}_{3}(\%)$ & $\mathrm{Glu}_{4}(\%)$ & $\mathrm{Glu}_{5}(\%)$ & $\mathrm{Glu}_{6}(\%)$ \\
\hline L1210-RFC & & & & & & & & \\
MTX & 1 & 11.6 & 67 & 20 & 13 & - & - & - \\
& 4 & 22.8 & 27 & 8 & 35 & 30 & - & - \\
& 24 & 83.4 & 6 & 1 & 12 & 57 & 24 & - \\
AMT & 1 & 18.7 & 60 & 30 & 10 & - & - & - \\
& 4 & 23.0 & 17 & 23 & 45 & 16 & - & - \\
& 24 & 64.7 & 21 & 3 & 7 & 25 & 35 & 7 \\
L1210-MFR & & & & & & & - \\
MTX & 1 & 5.4 & 100 & - & - & - & - & - \\
& 4 & 12.3 & 82 & 18 & - & - & - & - \\
& 24 & 24.5 & 50 & 21 & 18 & 12 & - & - \\
AMT & 1 & 12.9 & 59 & 41 & - & - & - & - \\
& 4 & 14.1 & 31 & 53 & 16 & - & - & - \\
& 24 & 42.4 & 21 & 32 & 19 & 19 & 6 & 3 \\
\hline
\end{tabular}

binding of antifolates. On a low folate diet the MTD for MTX and EDX was sevenfold lower than for mice on standard folate containing chow (Table 4). Even more substantial dose reductions (50- and 150-fold, respectively) were required for RTX and PMX in low folate mice as compared in mice on a standard diet (Table 4).

\section{Anti-leukaemic effect}

The anti-leukaemic activity of MTX, EDX, RTX and PMX was evaluated in mice (on either a standard or a low folate diet) that were inoculated with L1210-RFC and L1210MFR cells (Fig. 3). MTX and EDX displayed a low antileukaemic activity against L1210-RFC bearing mice on standard folate containing chow: ILS $213 \%$ and $263 \%$, respectively (Fig. 3a). Of note, both MTX and EDX showed markedly enhanced anti-leukaemic activity against L1210-RFC cells bearing mice on a folate deficient diet (Fig. 3b), represented by an ILS of $455 \%$ (1 out of 5 long term survivors) and $545 \%$ (2 out of 5 long term survivors), respectively. RTX and PMX were only marginally active against mice bearing L1210-RFC cells (ILS 144 and 138\%, respectively) (Fig. 3a). Regardless of the folate diet status,

Table 4 Maximum tolerated doses of antifolates for DBA/2 mice fed with a regular or folate-deficient chow

\begin{tabular}{lll}
\hline Antifolate & $\begin{array}{l}\text { Standard chow } \\
\text { (high folate) }(\mathrm{mg} / \mathrm{kg})\end{array}$ & $\begin{array}{l}\text { Folate-deficient } \\
\text { chow }(\mathrm{mg} / \mathrm{kg})\end{array}$ \\
\hline MTX & 100 & 15 \\
EDX & 100 & 15 \\
RTX & 10 & 0.2 \\
PMX & 150 & 1.0 \\
\hline
\end{tabular}

MTX, EDX, RTX and PMX were not active against mice inoculated with L1210-MFR cells (Fig. 3c, d).

Ex vivo analysis of folic acid binding capacity

In order to investigate whether mouse peritoneal residence may influence MFR expression on L1210-MFR cells, we analyzed total receptor levels and the percentage of unoccupied receptors in these cells immediately after sacrificing the mice. Furthermore, since receptor levels may also have been transiently down regulated due to internalization, L1210-MFR cells were again transferred into folate-free medium for $24 \mathrm{~h}$ to allow recycling of receptors to the cell surface. The total number of folate receptors in L1210MFR cells harvested from mice on standard chow was approximately half the number found in these cells when cultured in vitro under low folate conditions (Fig. 4). After in vivo harvesting of L1210-MFR cells, receptors appeared to be $80-90 \%$ occupied with circulating reduced folates. Total MFR binding capacity was almost fully recovered to the level of control L1210-MFR cells after ex vivo culture for $24 \mathrm{~h}$ in folate-free medium, suggesting that the original $50 \%$ reduction in $\left[{ }^{3} \mathrm{H}\right]$ folic acid binding capacity is due to internalization of receptors. Following treatment of L1210MFR bearing mice with the different antifolates these parameters were not changed (results not shown). Under low folate diet conditions in the mice total folate receptor$\left[{ }^{3} \mathrm{H}\right]-\mathrm{FA}$ binding activity of L1210-MFR was reduced by $40 \%$ as compared to cells maintained in vitro at low folate conditions. Interestingly, in contrast to cells on a high folate diet, MFR occupancy under low folate restrictions was only $30-40 \%$. After ex vivo culture of these cells in folate-free medium for $24 \mathrm{~h}$ restored original total receptor levels which were still occupied with folates for approx. $25 \%$. 
Fig. 3 Effects of antifolates on survival of mice bearing L1210RFC cells $(\mathbf{a}, \mathbf{b})$ or L1210-MFR cells $(\mathbf{c}, \mathbf{d})$ and fed with either a standard high folate chow $(\mathbf{a}, \mathbf{c})$ or a folate-deficient chow $(\mathbf{b}, \mathbf{d})$
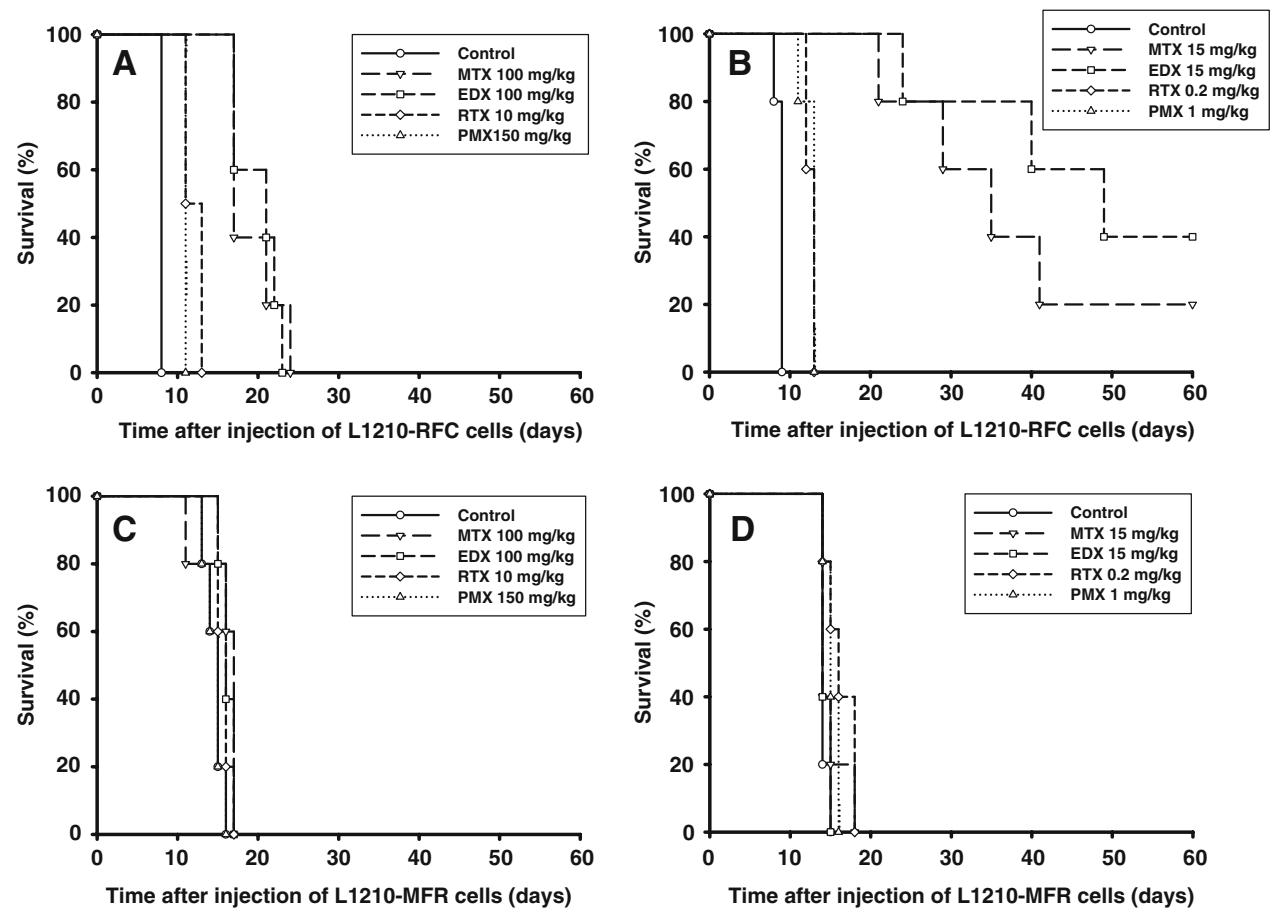

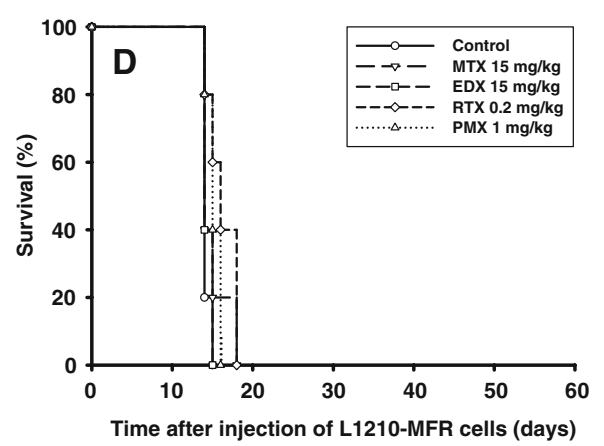

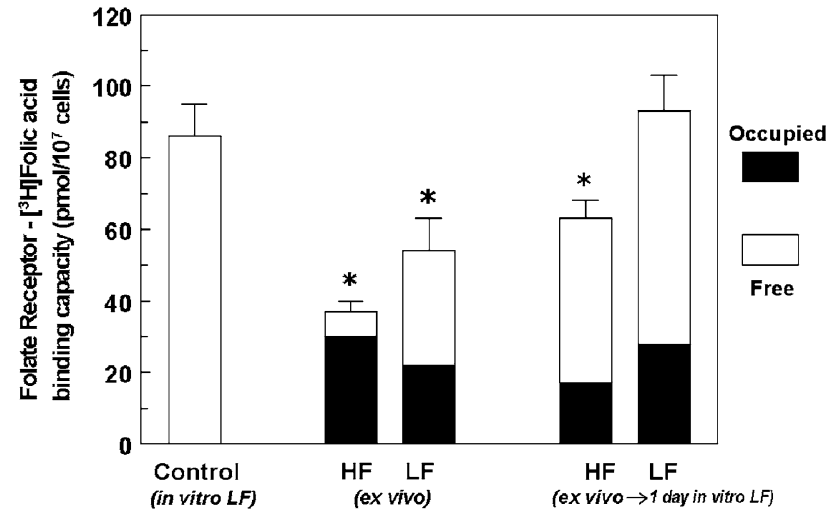

Fig. 4 Folate receptor occupancy in L1210-MFR cells isolated from L1210-MFR bearing mice on a standard high folate $(H F)$ or folatedeficient $(L F)$ chow. After harvesting the cells were recultured ex vivo in folate-deficient medium. The level of occupied receptors was determined after assessment of $\left[{ }^{3} \mathrm{H}\right]$ folic acid binding before (represents empty receptors) and after brief acid washing of the cells to remove occupied folate from the receptor. Further experimental details are described in the "Materials and methods". * Indicates significantly different $(P<0.01)$ in free receptors and total receptor binding capacity compared to in vitro control

\section{Discussion}

With MTX as its main representative, folate antagonists remain to have an established place in the oncologists' chemotherapeutic armature. Nowadays, second and third generations of folate antagonists are available based on the rationale design of compounds that harbour specific membrane transport, polyglutamylation and/or enzyme targeting properties [63]. Since inhibition of TS is the resultant of one or more of these parameters, we used the in situ TS inhibition assay as a tool to obtain insight how for new generation of antifolates this is translated into potential therapeutic activity $[32,48]$. In addition the data support further clinical development of AMT, one of the first antifolates to enter the clinic, which is currently being reevaluated for its clinical potential $[10,11]$. The first new clinical data warrant development of AMT. This good activity is probably related to its better polyglutamylation pattern compared to MTX.

The primary models used in this study included L1210 leukaemia cells that expressed either the classical RFC or MFR as the dominant route of (anti) folate cell entry. Previous notions that efficiency of RFC transport is a determining factor in the potency of hydrophilic antifolates [25, 31], were re-established by revealing good correlations between RFC affinities for antifolates and both TSI and $\mathrm{IC}_{50}$ values for cell growth inhibition (Fig. 1). We report here (Fig. 1) that similar types of correlations are observed for hydrophilic antifolate transport mediated via MFR. Nevertheless, results from the TS in situ assay with L1210-MFR cells provided evidence for some intriguing diversities in the cascade of MFR-mediated cell membrane translocation and targeting of TS. First, for several antifolates including MTX, MFR-mediated transport appears slower than RFC transport. However, a eightfold increase in exposure time (from 3 to $24 \mathrm{~h}$ ) resulted in an up to 3 -log (1,000-fold) increase in TS inhibitory effect, which is in line with earlier studies on the effect of duration of exposure on MTX 
cytotoxicity [30]. Second, compounds for which MFR had equally low affinities could still differ two orders of magnitude in potential to inhibit TS as was illustrated for AMT in comparison with MTX (Table 2). The marked differential potency by AMT is likely to be due to better transport and more efficient polyglutamylation than for MTX (Table 3), which allows a better retention and greater inhibitory effect on TS activity. Third, compounds for which MFR has similar binding affinities but have the ability to become polyglutamylated showed much more potent TS inhibitory effects than non-polyglutamatable compounds. This is best illustrated in a comparison of polyglutamatable MTX versus the non-polyglutamatable compounds PT523 and PT644, of which the latter compound even has a 24-fold gain in MFR binding affinity over PT523. Since both PT523 and PT644 showed excellent TS inhibitory potential for L1210-RFC cells (Table 2; Fig. 2a), this suggest that in L1210-MFR cells polyglutamylation may be a driving force to release antifolates from the receptor after MFR-mediated cell membrane translocation [59]. Fourth, antifolates for which MFR displays a high affinity may not necessarily confer a potent TS inhibitory effect. This may apply for CB3717 for which MFR has a binding affinity even greater than for folic acid (Table 1) [68], but this did not translate in a potent TS inhibitory effect (Table 2; Fig. 2b), presumably because the tight binding attenuates the intracellular release of CB3717 from MFR. Remarkably, PMX which has an even higher affinity to MFR displays a much lower TSI $_{50}$ than CB3717. However, PMX is an excellent substrate for FPGS, allowing a rapid polyglutamylation leading to an effective TS inhibition in line with the above stated role of polyglutamylation. Finally, although this study did not elaborate as much on the exact mechanism of MFR-mediated antifolates uptake in L1210-MFR cells, receptormediated endocytosis [47] or potocytosis [2]. For the potocytosis route some recent studies revealed a possible candidate transporter that may work in tandem with MFR to facilitate cell membrane translocation of antifolates. This transporter is referred to as proton coupled folate transporter (PCFT) [42], which functions optimally at mildly acidic $\mathrm{pH}$ and has a high affinity for folic acid and also for the antifolates PMX [43]. Since the substrate affinities of PCFT for many of the antifolates used in the present study are not yet known, it remains to be established whether PCFT may contribute to the uptake, in tandem with MFR or not, for a broad spectrum of antifolates drugs.

The DHFR inhibitors MTX and EDX displayed potential anti-leukaemic activity against L1210-RFC bearing mice. This is in accordance with a study by Sirotnak et al. [57] with L1210-RFC cells in another mouse strain. Our data show that dietary folate depletion could further enhance the anti-leukaemic effect of both drugs, most likely due to less competition for cellular uptake and polyglutamylation by circulating plasma folates [27]. In contrast to L1210-RFC cells, MTX and EDX did not evoke a substantial antileukaemic effect against L1210-MFR cells. This observation may be consistent with the low binding affinity of MFR for these compounds [68], which entails a relatively low level of receptor binding along with an attenuated capacity to displace natural folates from the receptor. The lack of antileukaemic activity by RTX and PMX relates to a known phenomenon that high plasma thymidine levels in mice serve as a salvage route to abolish any therapeutic effect $[22,54,62]$. Since this salvage effect is not affected by feeding mice a folate-deficient chow, this also counteracts an anti-leukaemic effect of RTX or PMX under these conditions. This comes along with the markedly reduced MTD's for these compounds in mice fed with a folate deficient chow. Consequently, plasma levels of these antifolates may be insufficient to achieve a critical state of MFR saturation that is required to elicit an anti-leukaemic effect. In addition, RTX and PMX do not have an anti-purine effect similar to MTX, which may also account for the inferior effects of these compounds in our in vivo model.

For several antifolates, in particular PMX, the therapeutic window is influenced by the patients' folate status [37, $38,54,62,70]$. The present study indicates that dietary folate modulation in mice provides a condition where folate receptors are less occupied by natural folates (Fig. 4). Consequently, this may allow enhanced binding of antifolates, especially those for which MFR has a binding affinity close to folic acid. In this context, some recently identified novel antifolates structures, i.e., BGC638 [61] and BGC945 [15], with the property of not being a substrate for RFC but possessing a good binding affinity for MFR, warrant further evaluation for selective MFR-mediated cell entry. Finally, recent observations that retinoic acid and histone deacetylase inhibitors can provoked a marked induction of MFR expression [41] may further facilitate selective targeting of MFR.

Acknowledgments This study was supported by the Netherlands Organization for Scientific Research (grant nr. 920-03-079). Dr. A. Rosowsky is acknowledged for providing the compound PT644.

Open Access This article is distributed under the terms of the Creative Commons Attribution Noncommercial License which permits any noncommercial use, distribution, and reproduction in any medium, provided the original author(s) and source are credited.

\section{References}

1. Aherne GW, Brown S (1999) The role of uracil misincorporation in thymineless death. In: Jackman AL (ed) Antifolate drugs in cancer therapy. Humana Press, Totowa, pp 409-421

2. Anderson RG, Kamen BA, Rothberg KG, Lacey SW (1992) Potocytosis: sequestration and transport of small molecules by caveolae. Science 255:410-411 
3. Assaraf YG (2006) The role of multidrug resistance efflux transporters in antifolate resistance and folate homeostasis. Drug Resist Updat 9:227-246

4. Assaraf YG (2007) Molecular basis of antifolate resistance. Cancer Metastasis Rev 26:153-181

5. Belkov VM, Krynetski EY, Schuetz JD, Yanishevski Y, Masson E, Mathew S, Raimondi S, Pui CH, Relling MV, Evans WE (1999) Reduced folate carrier expression in acute lymphoblastic leukemia: a mechanism for ploidy but not lineage differences in methotrexate accumulation. Blood 93:1643-1650

6. Benepal TS, Judson I (2005) ZD9331: discovery to clinical development. Anticancer Drugs 16:1-9

7. Braakhuis BJ, Jansen G, Noordhuis P, Kegel A, Peters GJ (1993) Importance of pharmacodynamics in the in vitro antiproliferative activity of the antifolates methotrexate and 10-ethyl-10-deazaaminopterin against human head and neck squamous cell carcinoma. Biochem Pharmacol 46:2155-2161

8. Chu E, Callender MA, Farrell MP, Schmitz JC (2003) Thymidylate synthase inhibitors as anticancer agents: from bench to bedside. Cancer Chemother Pharmacol 52(Suppl 1):S80-S89

9. Cocconi G, Cunningham D, Van Cutsem E, Francois E, Gustavsson B, Van Hazel G, Kerr D, Possinger K, Hietschold SM (1998) Open, randomized, multicenter trial of raltitrexed versus fluorouracil plus high-dose leucovorin in patients with advanced colorectal cancer. Tomudex Colorectal Cancer Study Group. J Clin Oncol 16:2943-2952

10. Cole PD, Drachtman RA, Smith AK, Cate S, Larson RA, Hawkins DS, Holcenberg J, Kelly K, Kamen BA (2005) Phase II trial of oral aminopterin for adults and children with refractory acute leukemia. Clin Cancer Res 11:8089-8096

11. Cole PD, Zebala JA, Alcaraz MJ, Smith AK, Tan J, Kamen BA (2006) Pharmacodynamic properties of methotrexate and Aminotrexate during weekly therapy. Cancer Chemother Pharmacol $57: 826-834$

12. Corona G, Giannini F, Fabris M, Toffoli G, Boiocchi M (1998) Role of folate receptor and reduced folate carrier in the transport of 5-methyltetrahydrofolic acid in human ovarian carcinoma cells. Int J Cancer 75:125-133

13. Duch DS, Banks S, Dev IK, Dickerson SH, Ferone R, Heath LS, Humphreys J, Knick V, Pendergast W, Singer S (1993) Biochemical and cellular pharmacology of 1843 U89, a novel benzoquinazoline inhibitor of thymidylate synthase. Cancer Res 53:810-818

14. Elnakat H, Ratnam M (2004) Distribution, functionality and gene regulation of folate receptor isoforms: implications in targeted therapy. Adv Drug Deliv Rev 56:1067-1084

15. Gibbs DD, Theti DS, Wood N, Green M, Raynaud F, Valenti M, Forster MD, Mitchell F, Bavetsias V, Henderson E, Jackman AL (2005) BGC 945, a novel tumor-selective thymidylate synthase inhibitor targeted to alpha-folate receptor-overexpressing tumors. Cancer Res 65:11721-11728

16. Hazarika M, White RM Jr, Booth BP, Wang YC, Ham DY, Liang CY, Rahman A, Gobburu JV, Li N, Sridhara R, Morse DE, Lostritto R, Garvey P, Johnson JR, Pazdur R (2005) Pemetrexed in malignant pleural mesothelioma. Clin Cancer Res 11:982-992

17. Henderson GB, Zevely EM (1984) Transport routes utilized by L1210 cells for the influx and efflux of methotrexate. J Biol Chem 259:1526-1531

18. Hooijberg JH, Broxterman HJ, Kool M, Assaraf YG, Peters GJ, Noordhuis P, Scheper RJ, Borst P, Pinedo HM, Jansen G (1999) Antifolate resistance mediated by the multidrug resistance proteins MRP1 and MRP2. Cancer Res 59:2532-2535

19. Jackman AL, Calvert AH (1995) Folate-based thymidylate synthase inhibitors as anticancer drugs. Ann Oncol 6:871-881

20. Jackman AL, Judson IR (1996) The new generation of thymidylate synthase inhibitors in clinical study. Expert Opin Investig New Drugs 5:719-736
21. Jackman AL, Kimbell R, Aherne GW, Brunton L, Jansen G, Stephens TC, Smith MN, Wardleworth JM, Boyle FT (1997) Cellular pharmacology and in vivo activity of a new anticancer agent, ZD9331 - a water-soluble, nonpolyglutamatable, quinazoline-based inhibitor of thymidylate synthase. Clin Cancer Res 3:911-921

22. Jackman AL, Taylor GA, Calvert AH, Harrap KR (1984) Modulation of anti-metabolite effects. Effects of thymidine on the efficacy of the quinazoline-based thymidylate synthetase inhibitor, CB3717. Biochem Pharmacol 33:3269-3275

23. Jackman AL, Taylor GA, Gibson W, Kimbell R, Brown M, Calvert AH, Judson IR, Hughes LR (1991) ICI D1694, a quinazoline antifolate thymidylate synthase inhibitor that is a potent inhibitor of L1210 tumor cell growth in vitro and in vivo: a new agent for clinical study. Cancer Res 51:5579-5586

24. Jackman AL, Theti DS, Gibbs DD (2004) Antifolates targeted specifically to the folate receptor. Adv Drug Deliv Rev 56:1111-1125

25. Jansen G (1999) Receptor- and carrier-mediated transport systems for folates and antifolates-exploitation for folate-based chemotherapy and immunotherapy. In: Jackman AL (ed) Antifolate drugs in cancer therapy. Humana Press, Totowa, pp 293-321

26. Jansen G, Kathmann I, Rademaker BC, Braakhuis BJ, Westerhof GR, Rijksen G, Schornagel JH (1989) Expression of a folate binding protein in L1210 cells grown in low folate medium. Cancer Res 49:1959-1963

27. Jansen G, Mauritz R, Drori S, Sprecher H, Kathmann I, Bunni M, Priest DG, Noordhuis P, Schornagel JH, Pinedo HM, Peters GJ, Assaraf YG (1998) A structurally altered human reduced folate carrier with increased folic acid transport mediates a novel mechanism of antifolate resistance. J Biol Chem 273:30189-30198

28. Jansen G, Westerhof GR, Kathmann I, Rademaker BC, Rijksen G, Schornagel JH (1989) Identification of a membrane-associated folate-binding protein in human leukemic CCRF-CEM cells with transport-related methotrexate resistance [published erratum appears in Cancer Res 1995 Sep 15;55(18):4203]. Cancer Res 49:2455-2459

29. Kamen BA, Capdevila A (1986) Receptor-mediated folate accumulation is regulated by the cellular folate content. Proc Natl Acad Sci USA 83:5983-5987

30. Keefe DA, Capizzi RL, Rudnick SA (1982) Methotrexate cytotoxicity for L5178Y/Asn-lymphoblasts: relationship of dose and duration of exposure to tumor cell viability. Cancer Res 42:16411645

31. Matherly LH, Goldman DI (2003) Membrane transport of folates. Vitam Horm 66:403-456

32. Mauritz R, Bekkenk MW, Rots MG, Pieters R, Mini E, Van Zantwijk CH, Veerman AJP, Peters GJ, Jansen G (1998) Ex vivo activity of methotrexate versus novel antifolate inhibitors of dihydrofolate reductase and thymidylate synthase against childhood leukemia cells. Clin Cancer Res 4:2399-2410

33. McCloskey DE, McGuire JJ, Russell CA, Rowan BG, Bertino JR, Pizzorno G, Mini E (1991) Decreased folylpolyglutamate synthetase activity as a mechanism of methotrexate resistance in CCRFCEM human leukemia sublines. J Biol Chem 266:6181-6187

34. McGuire JJ, Hsieh P, Coward JK, Bertino JR (1980) Enzymatic synthesis of folylpolyglutamates. Characterization of the reaction and its products. J Biol Chem 255:5776-5788

35. Mini E, Srimatkandada S, Medina WD, Moroson BA, Carman MD, Bertino JR (1985) Molecular and karyological analysis of methotrexate-resistant and -sensitive human leukemic CCRFCEM cells. Cancer Res 45:317-324

36. Moran RG (1999) Roles of folylpoly-gamma-glutamate synthetase in therapeutics with tetrahydrofolate antimetabolites: an overview. Semin Oncol 26:24-32

37. Niyikiza C, Hanauske AR, Rusthoven JJ, Calvert AH, Allen R, Paoletti P, Bunn PA Jr (2002) Pemetrexed safety and dosing strategy. Semin Oncol 29:24-29 
38. Peters GJ, Jansen G (2001) Folate homeostasis and antiproliferative activity of folates and antifolates. Nutrition 17:737-738

39. Peters GJ, Vander Wilt CL (1995) Thymidylate synthase as a target in cancer chemotherapy. Biochem Soc Trans 23:884-888

40. Peters GJ, Vander Wilt CL, Van Triest B, Codacci-Pisanelli G, Johnston PG, Van Groeningen CJ, Pinedo HM (1995) Thymidylate synthase and drug resistance. Eur J Cancer 31A:1299-1305

41. Qi H, Ratnam M (2006) Synergistic induction of folate receptor beta by all-trans retinoic acid and histone deacetylase inhibitors in acute myelogenous leukemia cells: mechanism and utility in enhancing selective growth inhibition by antifolates. Cancer Res 66:5875-5882

42. Qiu A, Jansen M, Sakaris A, Min SH, Chattopadhyay S, Tsai E, Sandoval C, Zhao R, Akabas MH, Goldman ID (2006) Identification of an intestinal folate transporter and the molecular basis for hereditary folate malabsorption. Cell 127:917-928

43. Qiu A, Min SH, Jansen M, Malhotra U, Tsai E, Cabelof DC, Matherly LH, Zhao R, Akabas MH, Goldman ID (2007) Rodent intestinal folate transporters (SLC46A1): secondary structure, functional properties, and response to dietary folate restriction. Am J Physiol Cell Physiol 293:C1669-C1678

44. Ratnam M, Marquardt H, Duhring JL, Freisheim JH (1989) Homologous membrane folate binding proteins in human placenta: cloning and sequence of a cDNA. Biochemistry 28:82498254

45. Rhee MS, Galivan J, Tyobeka EM, Sherman ML, Rosowsky A (1993) Effect of a novel antifolate, $\mathrm{N}$ alpha-(4-amino-4-deoxypteroyl)-N delta- hemiphthaloyl-L-ornithine (PT523), on growth of H35 rat hepatoma and HEPG2 human hepatoma cells. Adv Exp Med Biol 338:461-464

46. Rhee MS, Galivan J, Wright JE, Rosowsky A (1994) Biochemical studies on PT523, a potent nonpolyglutamatable antifolate, in cultured cells. Mol Pharmacol 45:783-791

47. Rijnboutt S, Jansen G, Posthuma G, Hynes JB, Schornagel JH, Strous GJ (1996) Endocytosis of GPI-linked membrane folate receptor-alpha. J Cell Biol 132:35-47

48. Rodenhuis S, McGuire JJ, Narayanan R, Bertino JR (1986) Development of an assay system for the detection and classification of methotrexate resistance in fresh human leukemic cells. Cancer Res 46:6513-6519

49. Rosowsky A (1999) PT523 and other aminopterin analogs with a hemiphthaloyl-L-ornithine side chain: exceptionally tight-binding inhibitors of dihydrofolate reductase which are transported by the reduced folate carrier but cannot form polyglutamates. Curr Med Chem 6:329-352

50. Rots MG, Pieters R, Peters GJ, Noordhuis P, Van Zantwijk CH, Henze G, Janka-Schaub GE, Veerman AJ, Jansen G (2000) Methotrexate resistance in relapsed childhood acute lymphoblastic leukaemia. Br J Haematol 109:629-634

51. Rumberger BG, Barrueco JR, Sirotnak FM (1990) Differing specificities for 4-aminofolate analogues of folylpolyglutamyl synthetase from tumors and proliferative intestinal epithelium of the mouse with significance for selective antitumor action. Cancer Res 50:4639-4643

52. Salazar MD, Ratnam M (2007) The folate receptor: what does it promise in tissue-targeted therapeutics? Cancer Metastasis Rev 26:141-152

53. Scagliotti GV, Kortsik C, Dark GG, Price A, Manegold C, Rosell R, O'Brien M, Peterson PM, Castellano D, Selvaggi G, Novello S, Blatter J, Kayitalire L, Crino L, Paz-Ares L (2005) Pemetrexed combined with oxaliplatin or carboplatin as first-line treatment in advanced non-small cell lung cancer: a multicenter, randomized, phase II trial. Clin Cancer Res 11:690-696

54. Schmitz JC, Grindey GB, Schultz RM, Priest DG (1994) Impact of dietary folic acid on reduced folates in mouse plasma and tissues.
Relationship to dideazatetrahydrofolate sensitivity. Biochem Pharmacol 48:319-325

55. Schornagel JH, Verweij J, De Mulder PH, Cognetti F, Vermorken JB, Cappelaere P, Armand JP, Wildiers J, De Graeff A, Clavel (1995) Randomized phase III trial of edatrexate versus methotrexate in patients with metastatic and/or recurrent squamous cell carcinoma of the head and neck: a European Organization for Research and Treatment of Cancer Head and Neck Cancer Cooperative Group study. J Clin Oncol 13:1649-1655

56. Shih C, Chen VJ, Gossett LS, Gates SB, MacKellar WC, Habeck LL, Shackelford KA, Mendelsohn LG, Soose DJ, Patel VF, Andis SL, Bewley JR, Rayl EA, Moroson BA, Beardsley GP, Kohler W, Ratnam M, Schultz RM (1997) LY231514, a pyrrolo[2,3-d]pyrimidine-based antifolate that inhibits multiple folate-requiring enzymes. Cancer Res 57:1116-1123

57. Sirotnak FM, Schmid FA, Samuels LL, DeGraw JI (1987) 10-Ethyl-10-deaza-aminopterin: structural design and biochemical, pharmacologic, and antitumor properties. NCI Monogr 127-131

58. Smith A, Hum MC, Winick NJ, Kamen BA (1996) A case for the use of aminopterin in treatment of patients with leukemia based on metabolic studies of blasts in vitro. Clin Cancer Res 2:69-73

59. Spinella MJ, Brigle KE, Freemantle SJ, Sierra EE, Goldman ID (1996) Comparison of methotrexate polyglutamylation in L1210 leukemia cells when influx is mediated by the reduced folate carrier or the folate receptor. Lack of evidence for influx route-specific effects. Biochem Pharmacol 52:703-712

60. Spinella MJ, Brigle KE, Sierra EE, Goldman ID (1995) Distinguishing between folate receptor-alpha-mediated transport and reduced folate carrier-mediated transport in L1210 leukemia cells. J Biol Chem 270:7842-7849

61. Theti DS, Bavetsias V, Skelton LA, Titley J, Gibbs D, Jansen G, Jackman AL (2003) Selective delivery of CB300638, a cyclopenta[g]quinazoline-based thymidylate synthase inhibitor into human tumor cell lines overexpressing the alpha-isoform of the folate receptor. Cancer Res 63:3612-3618

62. Van der Wilt CL, Backus HH, Smid K, Comijn L, Veerman G, Wouters D, Voorn DA, Priest DG, Bunni MA, Mitchell F, Jackman AL, Jansen G, Peters GJ (2001) Modulation of both endogenous folates and thymidine enhance the therapeutic efficacy of thymidylate synthase inhibitors. Cancer Res 61:3675-3681

63. Walling J (2006) From methotrexate to pemetrexed and beyond. A review of the pharmacodynamic and clinical properties of antifolates. Invest New Drugs 24:37-77

64. Wang X, Shen F, Freisheim JH, Gentry LE, Ratnam M (1992) Differential stereospecificities and affinities of folate receptor isoforms for folate compounds and antifolates. Biochem Pharmacol 44:1898-1901

65. Weitman SD, Lark RH, Coney LR, Fort DW, Frasca V, Zurawski VR Jr, Kamen BA (1992) Distribution of the folate receptor GP38 in normal and malignant cell lines and tissues. Cancer Res 52:3396-3401

66. Westerhof GR, Jansen G, Van Emmerik N, Kathmann I, Rijksen G, Jackman AL, Schornagel JH (1991) Membrane transport of natural folates and antifolate compounds in murine L1210 leukemia cells: role of carrier- and receptor-mediated transport systems. Cancer Res 51:5507-5513

67. Westerhof GR, Rijnboutt S, Schornagel JH, Pinedo HM, Peters GJ, Jansen G (1995) Functional activity of the reduced folate carrier in KB, MA104, and IGROV-I cells expressing folate-binding protein. Cancer Res 55:3795-3802

68. Westerhof GR, Schornagel JH, Kathmann I, Jackman AL, Rosowsky A, Forsch RA, Hynes JB, Boyle FT, Peters GJ, Pinedo HM, Jansen G (1995) Carrier- and receptor-mediated transport of folate antagonists targeting folate-dependent enzymes: correlates of molecular-structure and biological activity. Mol Pharmacol 48:459-471 
69. Yalowich JC, Kalman TI (1985) Rapid determination of thymidylate synthase activity and its inhibition in intact L1210 leukemia cells in vitro. Biochem Pharmacol 34:2319-2324

70. Zervos PH, Allen RH, Thornton DE, Thiem PA (1997) Functional folate status as a prognostic indicator of toxicity in clinical trials of the multitargeted antifolate LY231514. Eur J Cancer 33(Suppl 18)
71. Zhao R, Gao F, Hanscom M, Goldman ID (2004) A prominent low-pH methotrexate transport activity in human solid tumors: contribution to the preservation of methotrexate pharmacologic activity in HeLa cells lacking the reduced folate carrier. Clin Cancer Res 10:718-727 